RESENHA. Casanova, Marco Antônio. Nada a caminho: Impessoalidade, niilismo e técnica na obra de Martin Heidegger. Rio de Janeiro: Forense Universitária, 2006.

\title{
No meio do caminho
}

Cauê Polla*

\author{
"No meio do caminho tinha uma pedra \\ tinha uma pedra no meio do caminho \\ tinha uma pedra \\ no meio do caminho tinha uma pedra." \\ "Nel mezzo del cammin di nostra vita. \\ mi ritrovai per una selva oscura"
}

Nem Dante nem Drummond. Não estamos nós, nem a pedra, no meio do caminho. Nada está no meio do caminho, ou melhor, nada está a caminho - e é isto que pretende investigar o Prof. Marco Antônio Casanova indagando "até que ponto uma certa dimensão de nadidade não se insere hoje em todos os caminhos". A questão, importantíssima, à parte o calafrio estético que me causa a palavra nadidade e outros talvez incontornáveis - vocábulos heideggerianos, tem uma tripla raiz.

Antes, comentemos brevemente a primeira parte do título: nada a caminho - dois termos caros ao filósofo alemão. Do primeiro termo muito se pode falar, e muito foi dito na história da filosofia. Não por menos, Bergson em seu Evolução Criadora, ironicamente diagnostica o conceito nada como uma espécie de motor invisível da filosofia, diga-se, de uma má filosofia. Palavras mais suaves e cômicas são as de uma enciclopédia inglesa de filosofia: "Nada é um conceito que - ainda que indigesto - inspira admiração, muito estimado por escritores com ten-

* Mestrando em filosofia pelo Departamento de Filosofia da USP. 
dência mística ou existencialista, mas por muitos visto com ansiedade, náusea ou pânico. Ninguém parece saber lidar com ele, ainda que pessoas comuns em geral tenham pouquíssima dificuldade em dizer, ver, ouvir e fazer nada. Os filósofos, contudo, nunca se sentiram a vontade com este assunto". Do contrário, muito pouco se pode falar conceitualmente do segundo termo - desconheço um pensamento que não o de Heidegger que se tenha detido tão atentamente a essa questão. Deixemos as considerações acerca da expressão 'nada a caminho' para o leitor que empreender a leitura do livro.

Passemos ao subtítulo: impessoalidade, nilismo e técnica na obra de Martin Heidegger. Eis a tripla raiz da questão, que remete tanto ao nilismo entendido como "conjuntura originária do mundo contemporâneo [...] como tema do nosso tempo", como também à técnica - igualmente uma determinação fundamental do mundo contemporâneo. A análise do primeiro como "conjuntura fundamental do mundo contemporâneo implica necessariamente uma consideração atenta do domínio irrestrito do impessoal aí vigente". A trama conceitual - não expressamente tecida por Heidegger - pede ao intérprete um extenso conhecimento do pensamento do filósofo alemão, conhecimento este que o professor Casanova mostra ter de sobra. Talvez por isto a linguagem do livro adense em especialização e cause um certo cansaço ao leitor. Mas, ainda que densamente conceitual, o texto atinge muito bem seu objetivo, oferecendo uma atualização e rearticulação de pontos reflexivos que Martin Heidegger elaborou em diferentes etapas de seu pensamento.

A primeira parte se intitula Impessoalidade e Existência. Dividido em cinco grandes parágrafos germânicos - leia-se: enormes, abarcam 90 páginas - , é uma reconstrução exaustiva da temática do impessoal exposta em Ser e Tempo, e prepara o terreno para a interpretação que se encontra no segundo capítulo. Não há propriamente nada de original nesta reconstrução que se limita a apresentar detalhadamente os argumentos relacionados com o conceito de impessoal expostos na analítica existencial da opus magnum heideggeriana. A conhecida habilidade do professor Casanova como tradutor ajuda - e muito - pois ele não recorre ao uso abusivo dos termos alemães, mascarando uma possível inépcia: pelo contrário, a quase ausência de palavras em alemão (nas 189 páginas 
do livro, pode-se contá-las nos dedos) incentiva a leitura daqueles que desconhecem a língua. Todos os trechos citados são traduzidos de forma exemplar a partir da língua original.

Se não há nada de novo na paráfrase da argumentação, é de se destacar, contudo, alguns esclarecimentos conceituais que o professor Casanova oferece, como o que temos na pagina 63 - e também na página 157 do segundo capítulo sobre o termo Gestell -, concernente ao problema do falatório (Gerede), analisado de modo excelente. Lemos aí:

Se considerarmos apenas o uso corrente das palavras, a equiparação do discurso impessoal com o falatório tende a ser entendida como uma desqualificação da experiência cotidiana e como ponto de partida para a descrição de uma outra dimensão mais própria - a linguagem poética, por exemplo. No entanto, essa tendência provém necessariamente de uma perda de certas nuanças etimológicas inerentes aos dois vocábulos em alemão. O substantivo alemão Rede deriva-se diretamente do verbo reden, que significa 'falar'. O particípio dos verbos em alemão é feito na maior parte das vezes por meio da inserção da partícula 'ge'. Assim temos kaufen (comprar) e gekauft (comprado), lieben (amar) e geliebt (amado), finden (achar) e gefunden (achado). Essa relação entre presente e particípio passado é fundamental para a concepção heideggeriana da linguagem cotidiana. O que temos na cotidianidade mediana do ser-aí é falatório não porque podemos constatar empiricamente um esvaziamento da linguagem impessoal e porque sempre é possível acompanhar a falta de profundidade desses discursos. Ao contrário, é falatório porque não se realiza senão a partir de um ato já concluído - o que se confunde com a idéia mesma do particípio passado.

O autor desenvolve no primeiro capítulo uma linha de raciocínio precisa, desmembrando - isto é, analisando - o âmbito da analítica existencial, mostrando porque o conceito de impessoal não se restringe a alguma manifestação ôntica, sendo antes um problema estrutural de 
caráter ontológico (ontologia aqui entendida no sentido heideggeriano), e termina por problematizar:

\footnotetext{
mas, se por um lado é inquestionável que esse traço essencial da abertura não se reduz a nenhuma época em específico e não pode ser, conseqüentemente, confundido com o conceito ôntico de massa, é igualmente certo, por outro, que o domínio tenaz do impessoal alcança, no século XX uma dimensão simplesmente avassaladora.
}

A leitura da segunda parte intitulada Niilismo e Cientificidade é mais instigante. Dividida em quatro - igualmente enormes - parágrafos, apresenta uma interessante conexão de teses. O professor Casanova avança um pouco ainda no conceito de impessoal para mostrar como a partir deste Heidegger chega até o problema do ser propriamente dito, isto é, da compreensão de ser - o que resultará na já conhecida história do ser. O diagnóstico fundamental está no capítulo 07 , isto é, o problema da técnica como determinação de toda e qualquer compreensão de ser, técnica esta que precisa ser entendida como "destino histórico do ser-aí". O texto abrange o deslocamento do sentido da verdade como alethéia para o de veritas e certitudo. Verdade no primeiro sentido é o desvelamento do ser do ente, do ser mesmo de tudo aquilo que é, e passa paulatinamente a assumir o sentido de adequação e certeza desta adequação, preparando o solo para a metafísica da subjetividade.

Num passo posterior, o autor vincula o problema da subjetividade com o problema da vontade de poder nietzscheana, pensada por Heidegger em vários momentos, principalmente nos dois volumes monumentais dedicados a Nietzsche. A vontade de poder é interpretada como vontade de vontade, como consumação da metafísica moderna. O que resta saber é como se movimenta esta vontade num mundo tecnicamente disposto, isto é, como a compreensão de tudo aquilo que é tecnicamente disposto é veiculada por esta vontade. Resulta que a vontade é vontade de dominação sobre o mundo disposto como estoque, como algo já disponível através da representação total do sujeito. É isto que nos diz esta longa passagem elucidativa: 
A vontade técnica absolutiza radicalmente o plano ôntico, uma vez que posiciona desde o princípio a totalidade do ente como matéria-prima para o desenvolvimento de suas malhas de poder. Ao absolutizar radicalmente o plano ôntico, ela cinde o ser-aí do ser e obscurece maximamente a relação entre eles suportada pela compreensão. O ser-aí aliena-se, com isso, de si mesmo e também passa a vir à tona como fundo de reserva para a expansão do projeto técnico de uma vontade que circula incessantemente em si mesma. Como essa alienação de si ganha corpo a partir de um abandono do ser, o universo da técnica marca a culminação do niilismo; como esse nilismo se nutre constantemente de uma impossibilidade de o ser-aí conquistar o seu si-próprio a partir de uma apropriação originária de sua relação compreensiva com o ser, ele traz consigo ao mesmo tempo uma intensificação do domínio do impessoal. Essa intensificação dá ensejo ao aparecimento de uma experiência particular de nada: ela abre as portas para um tempo em que todos os caminhos conduzem ao fato de que nada está em última instância a caminho.

Antes de terminar esta brevíssima resenha me dou a liberdade de duas pequenas implicâncias. A primeira diz respeito a ausência de um texto que acredito ser essencial para a questão, a saber, $A$ época da imagem do mundo, por tratar exatamente da problemática da subjetividade moderna e da representação, abrindo também caminho para a vinculação com o problema da técnica e ciência moderna, e quiçá do niilismo. A segunda diz respeito ao título: porque localizar o questionamento na "obra de Martin Heidegger" e não no "pensamento de Martin Heidegger", lembrando o motto da edição completa de seus "escritos", Wege, nicht werke (caminhos, não obras)?. 
